\title{
Sediment trap efficiency of paddy fields at the watershed scale in a mountainous catchment in northwest Vietnam
}

\author{
Johanna I. F. Slaets ${ }^{1}$, Petra Schmitter ${ }^{2}$, Thomas Hilger ${ }^{1}$, Tran Duc Vien ${ }^{3}$, and Georg Cadisch ${ }^{1}$ \\ ${ }^{1}$ Institute of Plant Production and Agroecology in the Tropics and Subtropics, University of Hohenheim, \\ Garbenstrasse 13, Stuttgart, Germany \\ ${ }^{2}$ The International Water Management Institute, Nile Basin and East Africa Office, Addis Ababa, Ethiopia \\ ${ }^{3}$ Centre for Agricultural Research and Ecological Studies (CARES), Vietnam National University of \\ Agriculture, Hanoi, Vietnam
}

Correspondence to: J. I. F. Slaets (hanna.slaets@gmail.com)

Received: 8 October 2015 - Published in Biogeosciences Discuss.: 21 December 2015

Revised: 17 May 2016 - Accepted: 19 May 2016 - Published: 3 June 2016

\begin{abstract}
Composite agricultural systems with permanent maize cultivation in the uplands and irrigated rice in the valleys are very common in mountainous southeast Asia. The soil loss and fertility decline of the upland fields is well documented, but little is known about reallocation of these sediments within the landscape. In this study, a turbidity-based linear mixed model was used to quantify sediment inputs, from surface reservoir irrigation water and from direct overland flow, into a paddy area of 13 ha. Simultaneously, the sediment load exported from the rice fields was determined. Mid-infrared spectroscopy was applied to analyze sediment particle size. Our results showed that per year, $64 \mathrm{Mg} \mathrm{ha}^{-1}$ of sediments were imported into paddy fields, of which around $75 \%$ were delivered by irrigation water and the remainder by direct overland flow during rainfall events. Overland flow contributed one-third of the received sandy fraction, while irrigated sediments were predominantly silty. Overall, rice fields were a net sink for sediments, trapping $28 \mathrm{Mg} \mathrm{ha}^{-1} \mathrm{a}^{-1}$ or almost half of total sediment inputs. As paddy outflow consisted almost exclusively of silt- and clay-sized material, $24 \mathrm{Mg} \mathrm{ha}^{-1} \mathrm{a}^{-1}$ of the trapped amount of sediment was estimated to be sandy. Under continued intensive upland maize cultivation, such a sustained input of coarse material could jeopardize paddy soil fertility, puddling capacity and ultimately food security of the inhabitants of these mountainous areas. Preventing direct overland flow from entering the paddy fields, however, could reduce sand inputs by up to $34 \%$.
\end{abstract}

\section{Introduction}

Paddy cultivation is one of the most long-term sustainable cropping systems, as irrigated rice is the only major crop cultivated in monoculture for centuries without severe soil degradation (Bray, 1986; von Uexkuell and Beaton, 1992). Two mechanisms facilitate this continuing productivity: first, flooding applies suspended particles and soluble nutrients to the fields, and those contribute to the indigenous nutrient supply (Dobermann et al., 2003; Schmitter et al., 2011). Second, puddling creates an environment of high input and low breakdown of organic matter (Cao et al., 2006; Gong et al., 2007; Huang et al., 2015). As nutrient content of sediments is closely related to sediment particle size and puddling is favored by high clay contents (De Datta, 1981), the potential for long-term sustainable rice production is related to the soil texture in paddy fields.

Irrigated paddy fields, however, are not isolated elements in a landscape, as they are connected to surrounding upland areas. They receive sediments from those upland areas, both directly through overland flow, and indirectly from irrigation water released through surface reservoirs (Schmitter et al., 2012). These processes bring sediments into the rice fields, which can alter paddy soil texture (Schmitter et al., 2011). The vast majority of paddy fields in Vietnam are subject to these processes: $97 \%$ of Vietnamese rice is irrigated, and the main water source for irrigated rice in southeast Asia is water from surface reservoirs (FAO Aquastat, 2015). Therefore, most paddy areas receive sediment-conveying irrigation water. 
The amount and nature of sediments in irrigation water depends on their source, i.e., the upland fields surrounding both the paddy fields and the surface reservoirs. Traditionally, in the mountainous regions of northern Vietnam, Thailand and Laos as well as southern China, paddy systems have been located in the valleys, surrounded by shifting cultivation on the hills. In northern Vietnam, $60 \%$ of paddy cultivation is located in valleys of such hilly areas, on terraces that form cascades (Rutten et al., 2014).

In shifting cultivation systems, forest plots are cleared and burned, followed by cultivation of subsistence crops, rather than cash crops. Cultivation lasts for one to three seasons, after which the plots are left fallowed for a prolonged time to recover soil fertility (often a minimum of 6 times the cropping duration; Ziegler et al., 2009). Traditional shifting cultivation systems are very extensive in space and time, generating very limited runoff and erosion at the watershed scale (Ziegler et al., 2009). Gafur et al. (2003) reported soil losses amounting to $30 \mathrm{Mg} \mathrm{ha}^{-1} \mathrm{a}^{-1}$ for an upland area with shifting cultivations, while the regional average sediment yield was $1.2 \mathrm{Mg} \mathrm{ha}^{-1} \mathrm{a}^{-1}$, as $43 \%$ of soil loss from upland areas was captured by filtering elements in the lower area of the watershed. Chaplot and Poesen (2012) similarly found large sediment accumulations downslope in a slash and burn system in southeast Asia, pointing towards a low impact of this land use at the watershed scale. In recent years, under the influence of market mechanisms and population pressure, the traditional shifting cultivation systems on the slopes have been replaced by permanent upland cultivation (Ziegler et al., 2009). Implications of these land use changes have been studied in detail on the upland fields, and the increased erosion due to these changes are well documented. Chaplot et al. (2007) found water erosion rates of $6-24 \mathrm{Mg} \mathrm{ha}^{-1} \mathrm{a}^{-1}$ in an intensifying slash and burn system in northern Laos. Lacombe et al. (2015) determined that conversion of fallow into teak plantation vs. forest communities has opposite effects on catchment hydrology. Infiltration increased and runoff decreased for the forest communities, while the opposite was true for the teak conversion. These opposite consequences illustrate how the effects of disappearing fallow strongly depend upon the replacing vegetation. In our study area, maize and maize-cassava intercropping on steep slopes with clay topsoil texture in bounded plots resulted in plot-level erosion rates of up to $174 \mathrm{Mg} \mathrm{ha}^{-1} \mathrm{a}^{-1}$ (Tuan et al., 2014), coupled with a loss of soil organic matter reaching $1 \mathrm{Mg} \mathrm{ha}^{-1} \mathrm{a}^{-1}$ (Häring et al., 2014). Additionally, changes in texture occurred as fertile silt and clay fractions were exported from the upper and middle slope positions whereas sandy material was deposited at foot slope positions (Clemens et al., 2010). Differences in amount and texture of eroded material from upland fields could therefore entail a shift in the quality of sediment exchange between upland cultivation and valley paddy rice.

Increased erosion may therefore not only jeopardize the continued production of the cash crop maize on upland fields but also adversely affect the long-term sustainability of the food crop production in the paddies. Schmitter et al. (2010) showed that soil fertility in paddy cascades varies with distance to the irrigation channel, and thus established a link between sedimentation processes and soil properties. Rüth and Lennartz (2008) and Schmitter et al. (2011) found that variability of paddy soil texture and yield were a function of position along the catena, related to differential settling of sediments in irrigation water. If soil properties and yield are closely linked to sedimentation processes, then changes in amount and texture of the sediment inputs have a potential effect on long-term soil fertility and crop production, and hence on food security in the area, as rice is the main staple food crop.

In order to assess these risks, there is a need for reliable data on the amount and texture of sediments entering the paddy fields, but also on the quantity and quality of the material exported from the paddies. Because of their terraced structure, paddies can function as a sediment filter in the landscape (Kundarto et al., 2002, cited in Maglinao et al., 2003), but few studies have assessed both inputs and exports. Dung et al. (2009) monitored a watershed in northern Vietnam with shifting cultivation in the upper area of the catchment and paddy rice in the valley. Annually, for an experimental plot of $0.3 \mathrm{ha}$, between 11 and $29 \mathrm{Mg}$ of sediments entered the paddies, and from this amount, 27-63\% was trapped within the field and the remainder was exported with the runoff. The proportion that remained behind was mostly sandy, hence altering the soil texture in the experimental paddy plots.

While these results indicate that paddy fields act as a net sediment trap, their function might differ when upscaled to a larger area as sediment deposition changes over cascade length (Schmitter et al., 2010). Thus, at the watershed level, it is not clear whether paddy fields act as sediment sources or sinks. For example, Mai et al. (2013) found that paddies acted as a green filter, reducing runoff peaks, when their water storage capacity was not yet fully used by irrigation at the onset of the runoff event. But if the maximum storage capacity was already reached, runoff increased, as full paddies are not able to retain any water and so all overland flow was propelled through them, causing high runoff peaks at the catchment outlet.

Therefore, there is a need for a more detailed understanding of sediment fluxes and budgets in paddies at the watershed scale. Our specific aims were to (i) quantify the contribution of overland flow and irrigation water to the sediment inputs of a paddy rice area, (ii) determine if paddy fields are a net sediment source or a sink, (iii) assess the particle size distribution for the sediment input and export from paddy fields and (iv) evaluate the potential effects of within-watershed sediment reallocation on long-term soil fertility in Chieng Khoi watershed, northwest Vietnam. 
Table 1. Number of observations $(n)$, coefficient of determination $\left(R^{2}\right)$ and method used for stage-discharge relationship $(Q)$; number of observations and Pearson's correlation coefficient $\left(r^{2}\right)$ after 5-fold cross validation for suspended sediment concentration predictions (SSC). Details on the linear mixed model development can be found in Slaets et al. (2014).

\begin{tabular}{|c|c|c|c|c|c|}
\hline & \multicolumn{3}{|c|}{ Stage-discharge relationship $(Q)$} & \multicolumn{2}{|c|}{$\begin{array}{l}\text { Suspended sediment } \\
\text { concentration (SSC) }\end{array}$} \\
\hline & $n$ & $R^{2}$ & Method & $n$ & $r^{2}$ \\
\hline Channel (1) & 6 & 0.99 & Salt dilution & \multicolumn{2}{|c|}{ Identical to location 3} \\
\hline Channel (2) & 6 & 0.99 & Salt dilution & \multicolumn{2}{|c|}{ Identical to location 3} \\
\hline Channel (3) & 6 & 0.96 & Salt dilution & 327 & 0.72 \\
\hline River (A) & 9 & 0.99 & Area-velocity & 145 & 0.52 \\
\hline River (B) & 8 & 0.98 & Area-velocity & 71 & 0.66 \\
\hline River (main outlet) & 15 & 0.98 & Area-velocity & 228 & 0.56 \\
\hline
\end{tabular}

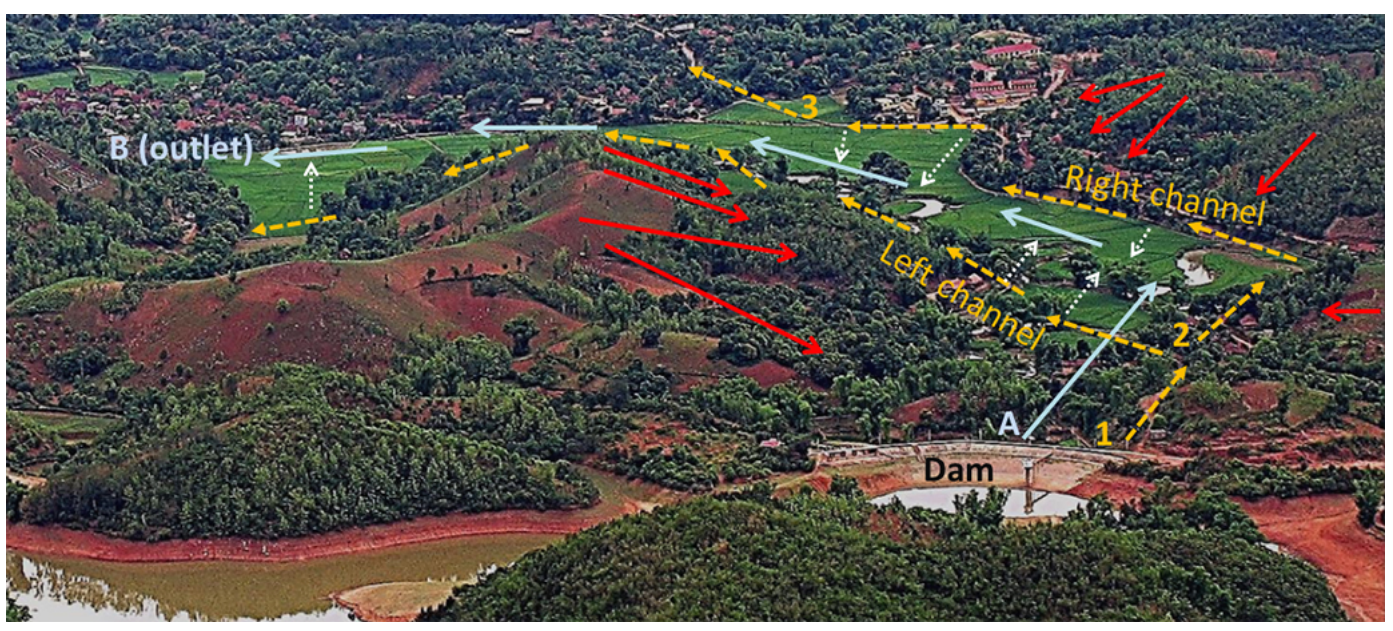

Figure 1. Sediment sources and water flows into and out of paddy rice fields in Chieng Khoi watershed. The dotted yellow arrows show the irrigation channel leaving the reservoir and splitting in two, feeding the two banks of paddy rice. The rice fields subsequently drain into the river, which is indicated by the blue arrows. During rainfall, runoff generated on the uplands flows into the irrigation channel and the paddy fields (red arrows). Measurement locations are indicated with numbers in the channel (1: reservoir outflow, 2: channel split, 3: channel leaving watershed) and with letters in the river (A: river before paddy fields drainage, B: river after paddy fields drainage).

\section{Material and methods}

\subsection{Study site}

The study was conducted in a small agricultural watershed, located in Chieng Khoi commune, Yen Chau district, Son La province, northwest Vietnam $\left(21^{\circ} 7^{\prime} 60^{\prime \prime} \mathrm{N}, 105^{\circ} 40^{\prime} 0^{\prime \prime} \mathrm{E}\right.$, 350 m a.s.l., Fig. S1 in the Supplement). The catchment is 200 ha in size, and sediment reallocation in a subcatchment of 50 ha which consists of 13 ha of paddy rice and 27 ha of upland fields was monitored in greater detail. In the area, the dominant soil types are Alisols and Luvisols (Clemens et al., 2010) and the climate is monsoonal, with a rainy season from April till October and average annual rainfall of around $1200 \mathrm{~mm}$. Land use in the watershed is characterized by maize and maize-cassava intercropping on the slopes, and irrigated rice in the valleys. The source of irrigation water is a surface reservoir that feeds a concrete irrigation channel, en- suring two rice crops per year: a spring crop from February till June, followed by a summer crop planted in July and harvested in October. The reservoir was formed by the damming of a river that originates in the karst mountains of the area. It has a capacity of $10^{6} \mathrm{~m}^{3}$ and a contributing area consisting of 490 ha of intensively cultivated upland fields and forest. The channel splits in two, just below the reservoir, and feeds two paddy rice areas ( 6.5 ha each), on the banks of a river that intersects the paddy fields. The irrigation water flows from the channel into the paddy fields, which drain into the river (Fig. 1).

\subsection{Hydrological monitoring}

Discharge and sediment concentration were monitored at five different locations in the catchment (Figs. 1, S1 and Table 1). As the irrigation management in the catchment disturbed the relationship between discharge and sediment concentration, 
a turbidity-based method was used to monitor the sediment concentration. Self-cleaning turbidity sensors (NEP395, McVan, Australia) were installed with the optical eye down in a vertically suspended pipe that could float with water level fluctuations, ensuring that the sensor remained approximately at the center point of flow.

Discharge was monitored using pressure sensors (Ecotech, Germany) and the stage-discharge relationship was established using the salt dilution method for the channel and the area-velocity method for the river (Herschy, 1995). Rainfall was measured with a tipping-bucket rain gauge $(0.1 \mathrm{~mm}$ accuracy, Campbell Scientific, USA) in the upper part of the catchment. The water level of the lake was recorded on a daily basis.

\subsection{Sediment concentration predictions}

Water samples were collected manually with a storm-chasing approach, where more samples were taken when water level and turbidity were rapidly changing. The time interval between two samples was adjusted for various stages of the hydrograph. During rapid changes in turbidity, samples were taken more frequently (up to 2 min apart) than at the end of the falling limb (up to 15 min apart). A typical sampled rainfall event thus consisted of 10-20 water samples, depending on the duration of the event. Additionally, base-flow samples were collected every 2 weeks. Total sample sizes for each location are shown in Table 1 and ranged from 71 to 327 samples. Each sample consisted of a $500 \mathrm{~mL}$ bottle. Sediment concentration in the samples was determined gravimetrically (ASTM, 2013) as recommended for samples with very high suspended sediment concentration (SSC), by letting the sediment settle overnight in cold storage $\left(<4{ }^{\circ} \mathrm{C}\right)$ and then siphoning off the supernatant followed by oven-drying of the sediment at $35^{\circ} \mathrm{C}$ until the sample weight remained constant.

Field calibration of the sensors resulted in continuous statistical predictions of sediment concentration for the 2-year study period (temporal resolution of $2 \mathrm{~min}$ ) which were obtained from a linear mixed model (Slaets et al., 2014). The linear mixed model is a regression-type model with SSC as a response variable and turbidity, discharge and cumulative rainfall as predictor variables. As the storm-based approach resulted in samples taken at very short consecutive time intervals (i.e., $2 \mathrm{~min}$ ), the assumption required for a traditional sediment rating curve of independence of errors was not fulfilled in this data set. Similarly, we found the variance to increase with increasing sediment concentration, violating the assumption of homoscedasticity. To account for temporal correlation in the observations, an error with a first-order autoregressive covariance structure was fitted to the data. The response variable was log transformed to stabilize the variance, as were the predictor variables of discharge and turbidity. The models were validated with 5-fold cross validation using a SAS macro described in Slaets et al. (2014).

\subsection{Separating sediment sources}

There are only two sources of sediment inputs to the paddy area: sediments in irrigation water from the surface reservoir and overland flow which enters the paddies via the channel. The paddies are isolated from surrounding uplands by the channel, and no overland flow enters the paddies without passing through the irrigation channel (Fig. 1). The monitoring locations in the concrete irrigation channel were chosen in order to separate these contributions of irrigation water from the surface reservoir, and Hortonian overland flow, to the paddy fields. The station situated furthest upstream in the channel (Location 1 in Fig. 1) was placed directly below the reservoir outlet, and thus monitored the discharge and water quality of the surface reservoir, which equals the sediment concentration of paddy inflow when it is not raining. An additional station (Location 2 in Fig. 1) was installed directly below the split of the concrete channel, and monitored only discharge, as the water quality here was the same as at Location 1. This second location quantified how much of the irrigation was flowing to the left arm of the irrigation channel after the split, and how much was going to the right arm. As the left channel ends at the watershed boarder and the water in the left channel was thus fully irrigated to the paddy fields in this watershed, and no further measurements were conducted in this branch of the channel. But the right channel leaves the watershed, exporting part of the irrigation water from the catchment. Therefore, a measurement station was installed downstream in the channel, at the point where the irrigation channel crosses into a neighboring watershed (Location 3 in Fig. 1). Thus, sediment inputs from reservoir outflow to both banks of the paddy area could be quantified.

In the absence of rainfall, Location 3 received water with the same sediment concentration as the reservoir outflow (Location 1). As there were no other water sources entering the concrete-lined waterway, the hydrological balance when it is not raining can be described by

$Q_{\text {in }}=Q_{\text {irr }}+Q_{\text {out }}$,

where $Q_{\text {in }}$ is the discharge measured at Location 2, consisting of the irrigation water originating from the reservoir, $Q_{\text {irr }}$ the irrigated discharge to the paddies, and $Q_{\text {out }}$ the discharge measured at Location 3, as not all irrigation water in the channel was used up fully in this catchment, but a part was transported further to irrigate rice in a watershed downstream. Since $Q_{\mathrm{in}}$ is the discharge measured at Location 2 and $Q_{\text {out }}$ is the discharge measured at Location 3, $Q_{\text {irr }}$ can be calculated as the difference in discharge between those two sites.

During rainfall events, Hortonian overland flow entered the channel directly from the upland fields (Fig. 1), changing the water balance to

$Q_{\text {in }}+Q_{\mathrm{pp}}+Q_{\text {of }}=Q_{\text {irr }}+Q_{\text {out }}$, 
where $Q_{\mathrm{pp}}$ is the direct rainfall into the channel and $Q_{\mathrm{of}}$ the overland flow that enters the channel from the upland area between the upstream and downstream locations. Overland flow was assumed to be Hortonian overland flow, rather than saturation excess overland flow, due to the fast-draining soils, high infiltration rates and landscape position of the channel, which is not situated in the lowest part of the valley. During rainfall, $Q_{\mathrm{pp}}$ could be calculated directly from the rainfall intensity and the surface area of the channel. Assuming that the irrigated discharge to the paddy fields prior to the onset of a particular rainfall event remained constant during the duration of that specific rainfall event, $Q_{\text {of }}$ can be calculated using Eq. (2). Flow component separation was performed with the statistical software R. Details of the procedure can be found in Schmitter et al. (2012).

\subsection{Sediment load estimates}

Instantaneous sediment loads at a time $i(i=1$ to $t)$ are generally estimated from the continuous discharge data and the continuous sediment concentration predictions according to

$\hat{L}_{i}=\hat{Q}_{i} \times \hat{C}_{i}$,

where $\hat{L}_{i}$ is the estimated instantaneous load at time $i$ in $\mathrm{g} \mathrm{s}^{-1}, \hat{Q}_{i}$ is the estimated discharge at time $i$ in $\mathrm{m}^{3} \mathrm{~s}^{-1}$ and $\hat{C}_{i}$ is the estimated concentration at time $i$ in $\mathrm{g} \mathrm{m}^{-3}$. These concentrations for each specific location were derived from the continuous sediment predictions using the locationspecific SCC regression function, where the time series consisted of 2 min intervals. As such, the estimated monthly or annual sediment load $\hat{L}_{1 \text { to } t}$ in grams can be computed by summing up the instantaneous loads, across $t$ measurement intervals of turbidity and discharge:

$\hat{L}_{1 \text { to } t}=\sum_{i=1}^{t}\left(\hat{L}_{i} \times 120\right)$.

Rainfall does not contain sediment, so $Q_{\mathrm{pp}}$ makes no contribution to the sediment load. The full sediment load balance for the irrigation channel then equals

$L_{\text {in }}+L_{\text {of }}=L_{\text {irr }}+L_{\text {out }}$,

where $L_{\text {in }}$ is the sediment load at Location $2, L_{\text {of }}$ is the sediment load brought into the channel by direct runoff during rainfall events, $L_{\text {irr }}$ is the load irrigated to the paddies and $L_{\text {out }}$ is the sediment load exported from the channel at Location 3, with $L_{\mathrm{in}}, L_{\mathrm{irr}}$ and $L_{\text {out }}$ in Eq. (5) computed using Eq. (4). The sediment load from direct runoff during rainfall is then the only remaining unknown in Eq. (5): the sediment concentration $c_{\text {in }}$ of $Q_{\text {in }}$ was monitored at Location 1, and $c_{\text {out }}$ of $Q_{\text {out }}$ at Location 3. The irrigated discharge to the paddy fields, $Q_{\text {irr }}$, had the same sediment concentration as the discharge exported from the watershed at Location 3, assuming full mixing. The sediment load from overland flow can then be calculated from

$L_{\text {of }}=\left[\left(Q_{\text {irr }} \times c_{\text {out }}\right)+\left(Q_{\text {out }} \times c_{\text {out }}\right)-\left(Q_{\text {in }} \times c_{\text {in }}\right)\right]$.

In the river, the water sources are paddy outflow and reservoir overflow. The measurement stations were installed in a similar manner as they were in the irrigation channel, with one station upstream and one downstream of the paddy fields (Locations A and B in Fig. 1). The only sediment input between these two locations was drainage from paddy fields and fish ponds in the paddy area. The river receives outflow from both banks of paddy fields, and we only monitored the overland flow entering the right bank. Therefore, in order to quantify the net sediment balance for the paddy fields, the assumption is made that the upland fields on the left bank of the river generated the same amount of erosion as those on the right bank, as the areas are very similar in land use, slope and size (17 and 20 ha of contributing area).

There was one additional measurement location in the river further downstream (overall outlet, Fig. S1), at the outlet of a larger watershed of $2 \mathrm{~km}^{2}$ in which the monitored paddy area was nested, in order to assess scaling effects on paddy watershed sediment losses.

In order to calculate $95 \%$ confidence intervals on the sediment load, a bootstrap method was used that accounts for uncertainty in the discharge and sediment concentration predictions (Slaets et al., 2016; Appendix Sect. A). The number of bootstrap replicates was 2000. As the direct sediment load estimation described in Eq. (3) is typically biased downwards when concentration and discharge are predicted on the logtransformed scale (Ferguson, 1986), taking the medians of the bootstrap replicates is a simple method for bias removal (Efron and Tibshiriani, 1993). Therefore, the estimated sediment loads reported in this study are the medians of the bootstrap empirical distribution, rather than the direct estimates from Eq. (3) (Slaets et al., 2016; Appendix Sect. A).

\subsection{Sediment texture with mid-infrared spectroscopy}

Texture analysis with conventional methods typically requires a minimum of $1 \mathrm{~g}$ of the sample. Collecting this amount can be unpractical when the sediment is obtained from water samples with a very low sediment concentration. The base-flow sediment concentrations in this study fluctuated around $250 \mathrm{mg} \mathrm{L}^{-1}$, which would mean that samples of approximately $4 \mathrm{~L}$ would have to be collected, transported, refrigerated for storage and analyzed. Diffuse reflectance Fourier transform mid-infrared spectroscopy (MIRS) is a practical alternative to conventional methods for determining particle size distribution on sediment samples, as only $25 \mathrm{mg}$ is needed for analysis and the measurement is not destructive (Schmitter et al., 2010). From the samples collected for sediment concentration analysis, the sediments of a total of 152 samples were selected to cover the full range of locations, seasons and flow regimes, and analyzed for texture. A Bruker Tensor-27 mid-infrared spectroscope (Bruker Op- 


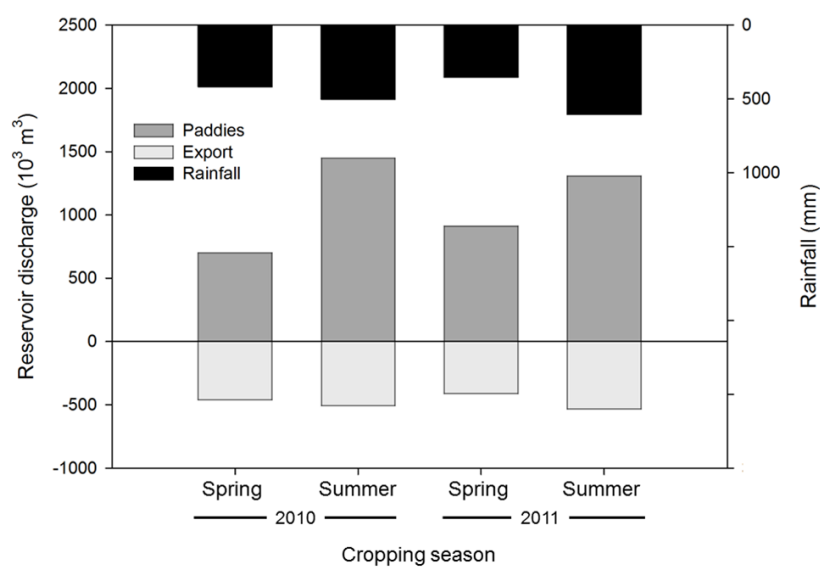

Figure 2. Total discharge from the reservoir irrigated to the 13 ha paddy area draining between Locations A and B in the river, and total discharge exported (negative on the $y$ axis) from the subwatershed via the irrigation channel at Location 3, per rice crop (spring, summer) per year, and amount of rainfall per rice crop per year.

tik, Germany) was used and three analytical replicates were measured per sample. Baseline correction and atmospheric compensation were performed on each spectrum before averaging the analytical replicates. As the MIRS method requires a subset of the samples to be analyzed with conventional wet analytical methods for calibration and validation, laser diffraction with a Coulter LS 200 (Beckman Coulter, Germany) was performed on 50 samples. Organic matter and carbonates were destroyed prior to laser diffraction analysis and samples were shaken overnight with a dispersing agent ( $5 \mathrm{~mL} 2 \%$ sodium hexametaphosphate for $5 \mathrm{~g}$ soil). Three analytical replicates were done per sample.

Sand, silt and clay were predicted from the spectral data using partial least squares regression (PLSR; Wold, 1966). All spectral manipulation and model selection was performed using Quant2 package within the software Opus 7.0 (Bruker Optik, Germany). Models were evaluated with leaveone-out cross validation. Opus offers several spectral processing techniques to enhance spectral information and reduce noise. The selection of the most suitable method can be automatized using the optimization function, which selects the method resulting in the highest $r^{2}$ of observed vs. predicted values after cross validation. For sand, the preprocessing method was the calculation of the second derivative of the spectra, which can help to emphasize pronounced but small features over a broad background. After validation, an $r^{2}$ of 0.81 was obtained. For silt, a multiplicative scattering correction was applied, which performs a linear transformation of each spectrum in order to best match the mean spectrum of the whole set, and the model resulted in an $r^{2}$ of 0.83 . For clay, no satisfactory model could be obtained, and so the clay percentage was calculated as the remaining amount of sediment after subtracting the sand and silt fractions.
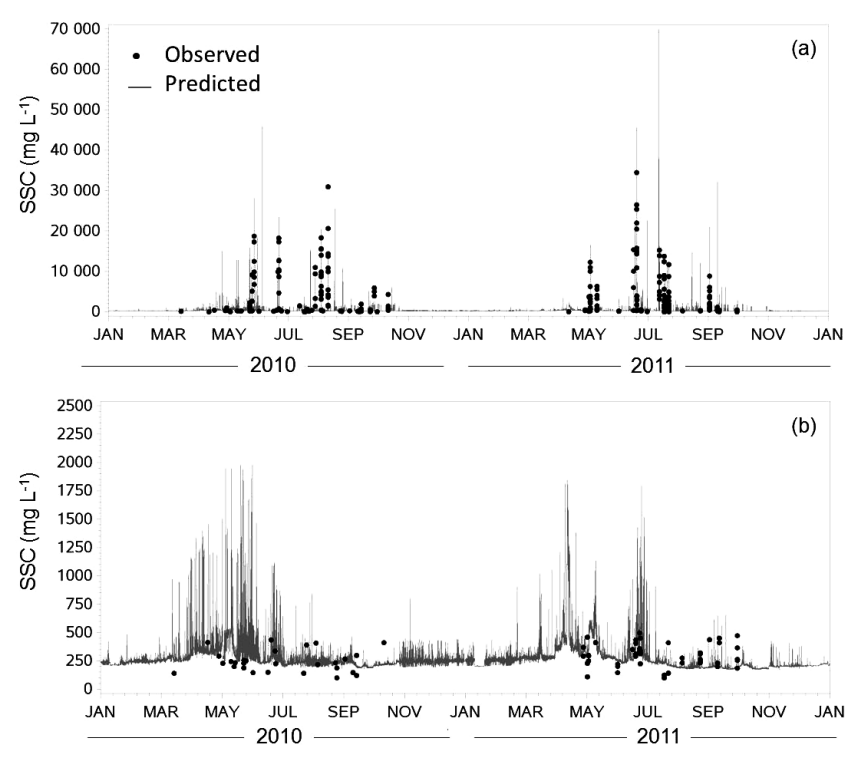

Figure 3. Observed and predicted sediment concentrations (in $\mathrm{mg} \mathrm{L}^{-1}$ ) for Location 3 in the irrigation channel (a), and zooming in on base flow, showing only non-event samples and concentration predictions (b).

\section{Results}

\subsection{Hydrological processes driving sediment flows}

Model fit for the discharge rating curves varied between locations, with the coefficient of determination ranging from 0.96 to 0.99 (Table 1). As expected, accuracy of the sediment rating curves was lower than that of the discharge rating curves, and explained between 52 and $72 \%$ of variability in the data after cross validation.

In 2010, a total of $920 \mathrm{~mm}$ of rainfall was measured between April and October with the onset of the rainy season in April, whereas in 2011, $961 \mathrm{~mm}$ fell but rains were delayed. This delay resulted in less rainfall in April-May and a precipitation peak in July, with $780 \mathrm{~mm}$ of the annual rain falling between June and October. The lower amount of precipitation in the spring of 2011 resulted in a lower amount irrigated during that period (Fig. 2). Although the total amount of water irrigated to the 13 ha of paddy fields was similar, i.e., $3978 \times 10^{3}$ in 2010 and $4021 \times 10^{3} \mathrm{~m}^{3}$ in 2011 , the seasonal distribution of the irrigated amounts varied between the study years. As the rainy season started late in 2011, there was more water irrigated during the first rice season (FebruaryJune) in $2011\left(913 \times 10^{3} \mathrm{~m}^{3}\right)$ than in $2010\left(700 \times 10^{3} \mathrm{~m}^{3}\right)$. The opposite was true for the summer crop (July-October), during which $1308 \times 10^{3} \mathrm{~m}^{3}$ was irrigated in 2011 compared with $1448 \times 10^{3} \mathrm{~m}^{3}$ in 2010 . As the rains came late in 2011 , the reservoir was not filled up yet in July at the start of the summer crop, and so there was less irrigation water available.

Variation in rainfall throughout the year was also reflected in the sediment concentration of the irrigation water. In the 
Table 2. Average sediment particle size distribution measured at the different measurement locations for the different components of the paddy area sediment balance.

\begin{tabular}{lrrr|rrr|rr|rr}
\hline Sediment source & \multicolumn{3}{c|}{ \% Sand } & \multicolumn{3}{c|}{ \% Silt } & \multicolumn{3}{c}{ \% Clay } \\
\hline & Min & Avg & Max & Min & Avg & Max & Min & Avg & Max \\
\hline Reservoir water - Location 1 & 0 & 34 & 50 & 14 & 34 & 58 & 0 & 32 & 86 \\
Overland flow & 0 & 50 & 100 & 0 & 30 & 61 & 0 & 20 & 61 \\
River - Location A & 29 & 61 & 89 & 9 & 22 & 40 & 0 & 17 & 80 \\
River - Location B & 1 & 47 & 74 & 17 & 33 & 47 & 9 & 20 & 53 \\
\hline
\end{tabular}

irrigation channel, the median sediment concentration during base-flow regime was $240 \mathrm{mg} \mathrm{L}^{-1}$. The predicted baseflow sediment concentration fluctuated seasonally, peaking in April and May 2010 and in April, May and June 2011 (Fig. 3b), resulting in a higher median in those months, between 350 and $430 \mathrm{mg} \mathrm{L}^{-1}$. As for sediment texture, the sand content of the sediments in the irrigation channel during base-flow regime $(n=18)$ varied between 0 and $50 \%$ with an average of $34 \%$ over the whole study period (Table 2). The silt content ranged from 14 to $58 \%$ with an average of $34 \%$. For clay, the minimum measured content was $0 \%$, the maximum was $86 \%$ and the average clay content of the sediments was $32 \%$.

The median sediment concentration in the irrigation channel during rainfall events was $1200 \mathrm{mg} \mathrm{L}^{-1}$, and the concentration reached a maximum of $70000 \mathrm{mg} \mathrm{L}^{-1}$ (Fig. 3a) during the rainfall event on 12 July 2011, in which $70 \mathrm{~mm}$ of precipitation fell in just over $1 \mathrm{~h}$. The water samples taken during rainfall events in the channel $(n=109)$ showed a different particle size distribution than those taken during base flow, with higher proportions of coarser particles: on average, $50 \%$ of sand, $30 \%$ of silt and $20 \%$ of clay were measured during the full duration of rainfall event sampling (Table 2). When only looking at the peak sediment concentration of each event (thus excluding rising and falling limb samples), sand concentrations were higher and varied from 29 to $94 \%$ with an average of $72 \%$ for the 14 measured events.

In the river, the median of the suspended sediment concentration predictions was $300 \mathrm{mg} \mathrm{L}^{-1}$ during periods of no rainfall (data not shown). There were no differences in baseflow concentrations between Locations A and B. The river sediment concentrations were very little affected by overland flow as the paddy fields buffered inputs from Hortonian overland flow, and so the maximum concentrations in the river only reached up to $5000 \mathrm{mg} \mathrm{L}^{-1}$. Water samples of Location $A$ in the river, upstream of the paddy fields, had on average $61 \%$ sand, $22 \%$ silt and $17 \%$ clay $(n=12$, Table 2$)$. After paddy discharge, the river sediment texture on average had $47 \%$ sand, $33 \%$ silt and $20 \%$ clay $(n=13$, Table 2$)$.

In the river at the overall outlet of the larger catchment, the median base-flow concentration was $190 \mathrm{mg} \mathrm{L}^{-1}$ (data not shown). Between Location B and the overall outlet, an additional 47 ha of paddy rice drain into the river, adding filtered

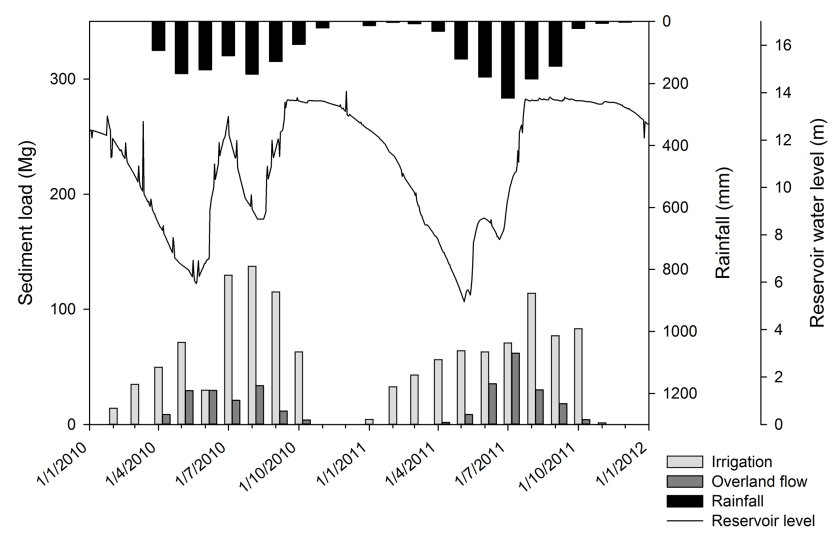

Figure 4. Monthly variations in rainfall, reservoir water level and sediment load inputs to the paddy fields, both from the surface reservoir and from overland flow.

irrigation water with lower sediment content to the river, resulting in a lower sediment concentration during base flow at the overall outlet compared with Location B. During rainfall events, concentration increased at the overall outlet, with a maximum peak of $22000 \mathrm{mg} \mathrm{L}^{-1}$ on 5 June 2010 when $46 \mathrm{~mm}$ of rain fell in $160 \mathrm{~min}$. These peak concentrations during rainfall events were higher than those measured at the same time at Location B. As there are point sources of overland flow that reach the stream directly at the overall outlet, the river stretch downstream of Location B is not as completely isolated from overland flow as it is until Location $\mathrm{B}$, where the paddy fields buffered the input of runoff from upland fields, explaining the difference in peak concentrations between these two stations.

\subsection{Seasonal sediment load trends in the irrigation system}

Monthly sediment loads from irrigation water (Fig. 4) reflected changes in the suspended sediment concentration (Fig. 3b), related to fluctuations in the level of the surface reservoir (Fig. 4) as well as changes in amount of water irrigated to the paddy fields. The first rice crop (from February till June) received about half the water volume of the second crop (Fig. 2), as a smaller area of the paddy fields was culti- 
Table 3. Sediment inputs from irrigation water and overland flow from the 37 ha upland area in the subwatershed, and sediment export and trapping by the 13 ha paddy area (Figs. 1 and S1). Loads are estimated as the median of the bootstrap estimates (Med) and therefore do not always sum up exactly within columns, and $95 \%$ confidence intervals are shown (LL is the lower limit, UL is the upper limit) in Mg per year $\left(\mathrm{Mg} \mathrm{a}^{-1}\right)$.

\begin{tabular}{|c|c|c|c|c|c|c|}
\hline \multirow[b]{3}{*}{ Sediment source } & \multicolumn{6}{|c|}{ Sediment load $\left(\mathrm{Mg} \mathrm{a}^{-1}\right)$} \\
\hline & \multicolumn{3}{|c|}{2010} & \multicolumn{3}{|c|}{2011} \\
\hline & LL & Med & UL & LL & Med & UL \\
\hline \multicolumn{7}{|l|}{ Reservoir water } \\
\hline Total to channels & 617 & 806 & 1123 & 587 & 762 & 1331 \\
\hline Irrigated to paddy area & 492 & $\begin{array}{r}646 \\
(77 \%)\end{array}$ & 903 & 496 & $\begin{array}{r}612 \\
(74 \%)\end{array}$ & 1085 \\
\hline Exported via channel & 124 & 160 & 222 & 117 & 150 & 248 \\
\hline Spillover to river & nd & nd & nd & 917 & 1556 & 18128 \\
\hline \multicolumn{7}{|l|}{ Overland flow } \\
\hline Total to channels & 121 & 249 & 303 & 129 & 278 & 516 \\
\hline Irrigated to paddy area & 119 & $\begin{array}{r}193 \\
(23 \%)\end{array}$ & 302 & 110 & $\begin{array}{r}219 \\
(26 \%)\end{array}$ & 517 \\
\hline Exported via channel & 36 & 56 & 88 & 35 & 59 & 135 \\
\hline Total paddy input & & $\begin{array}{r}839 \\
(100 \%)\end{array}$ & & & $\begin{array}{r}832 \\
(100 \%)\end{array}$ & \\
\hline Paddy outflow & nd & nd & nd & -361 & $\begin{array}{r}469 \\
(56 \%)\end{array}$ & 2555 \\
\hline Net paddy balance & nd & nd & nd & -1625 & $\begin{array}{r}363 \\
(44 \%)\end{array}$ & 1586 \\
\hline Paddy balance per ha & & & & & $a^{-1} a^{-1}$ & \\
\hline
\end{tabular}

nd stands for not determined.

vated during the spring season. This resulted in a lower sediment input from irrigation during the spring season $(200 \mathrm{Mg}$ in $2010,263 \mathrm{Mg}$ in 2011) compared with the summer season (445 Mg in 2010, $346 \mathrm{Mg}$ in 2011). The difference in load between the spring crop and the summer crop was smaller in 2011, as the rains came late that year. Consequently, the reservoir was depleted during the spring rice crop and the first rains fell on a much smaller volume of water, increasing the sediment concentration in the reservoir, thus causing the higher sediment load compared with 2010. In the summer season of 2011, the irrigated amount of water was $10 \%$ less than in 2010 (Fig. 2), as the rains came late and the irrigation manager wanted to preserve water. Overall, the largest sediment inputs from irrigation occurred in August in both years of the study (Fig. 4), with $137 \mathrm{Mg}$ of sediments in 2010 and $114 \mathrm{Mg}$ in 2011.

Even though the sediment concentration in the overland flow was orders of magnitude higher than the concentration in the irrigation water (Fig. 3), over a full year, the contribution of irrigation water was about 3 times larger than the contribution of overland flow (Table 3). As the rainy season starts in April, paddy water inputs from overland flow play a more important role during the second rice crop. The contri- bution of overland flow was almost negligible during the first rice crop, particularly in 2011 when the onset of the rains was late and the volume of overland flow was much smaller during the first crop (Fig. 4). During that spring cropping season of 2011, the contribution of overland flow to the sediment input of the paddy fields was negligible, reaching only $46 \mathrm{Mg}$ vs. $263 \mathrm{Mg}$ from irrigation water. But during July 2011, the month in the study which had the highest rainfall $(247 \mathrm{~mm})$, direct overland flow provided almost as much sediment to the paddy fields as irrigation water from the reservoir $(62 \mathrm{Mg}$ vs. $71 \mathrm{Mg}$ ).

\subsection{Sediment budget for paddy fields}

Irrigation water from the surface reservoir removed $806 \mathrm{Mg}$ of sediments from the reservoir in 2010 (Table 3). Of this amount, $646 \mathrm{Mg}$ entered paddy fields through irrigation and $160 \mathrm{Mg}$ were exported from the subwatershed, as the irrigation channel crosses the watershed border into a neighboring catchment. In 2011, the sediment load from the irrigation water was similar with $762 \mathrm{Mg}$, of which $612 \mathrm{Mg}$ entered the rice fields, and $150 \mathrm{Mg}$ were exported to the next catchment. Using the average textural class percentages of the surface reservoir outflow, irrigation water can be estimated to have 
Table 4. Texture-specific sediment inputs from irrigation water and overland flow from the 37 ha upland area in the subwatershed, and texture-specific sediment export and trapping by the 13 ha paddy area (Figs. 1 and S1).

\begin{tabular}{|c|c|c|c|c|c|c|}
\hline \multirow[b]{3}{*}{ Sediment source } & \multicolumn{6}{|c|}{$\operatorname{Load}\left(\mathrm{Mg} \mathrm{a}^{-1}\right)$} \\
\hline & \multicolumn{3}{|c|}{2010} & \multicolumn{3}{|c|}{2011} \\
\hline & Sand & Silt & Clay & Sand & Silt & Clay \\
\hline \multicolumn{7}{|l|}{ Reservoir water } \\
\hline Total to channels & 274 & 274 & 258 & 259 & 259 & 244 \\
\hline Irrigated to paddies & $\begin{array}{r}220 \\
(70 \%)\end{array}$ & $\begin{array}{r}220 \\
(79 \%)\end{array}$ & $\begin{array}{r}207 \\
(84 \%)\end{array}$ & $\begin{array}{r}208 \\
(66 \%)\end{array}$ & $\begin{array}{r}208 \\
(76 \%)\end{array}$ & $\begin{array}{r}196 \\
(82 \%)\end{array}$ \\
\hline Exported via channel & 54 & 54 & 51 & 51 & 51 & 48 \\
\hline Spillover to river & nd & nd & nd & 950 & 343 & 265 \\
\hline \multicolumn{7}{|l|}{ Overland flow } \\
\hline Total to channels & 124 & 75 & 50 & 139 & 83 & 56 \\
\hline Irrigated to paddies & $\begin{array}{r}96 \\
(30 \%)\end{array}$ & $\begin{array}{r}58 \\
(21 \%)\end{array}$ & $\begin{array}{r}39 \\
(16 \%)\end{array}$ & $\begin{array}{r}109 \\
(34 \%)\end{array}$ & $\begin{array}{r}66 \\
(24 \%)\end{array}$ & $\begin{array}{r}44 \\
(18 \%)\end{array}$ \\
\hline Exported via channel & 28 & 17 & 11 & 30 & 17 & 12 \\
\hline Paddy input (100\%) & 316 & 278 & 246 & 317 & 274 & 240 \\
\hline Paddy outflow & nd & nd & nd & 2 & 326 & 141 \\
\hline Net paddy balance & nd & nd & nd & $\begin{array}{r}+315 \\
(99 \%)\end{array}$ & -52 & $\begin{array}{r}+99 \\
(40 \%)\end{array}$ \\
\hline
\end{tabular}

nd stands for not determined.

contributed $208 \mathrm{Mg}$ of sand, $208 \mathrm{Mg}$ of silt and $196 \mathrm{Mg}$ of clay to the paddy rice fields in the watershed in 2011 (Table 4). As there were not enough samples analyzed to obtain continuous predictions of the different particle size classes using a regression model, simple averages were used for the texture loads. In this sense, all sand, silt and clay loads are more a semi-quantitative estimate that provides an order of magnitude, rather than an exact figure.

For the upland area bordering both irrigation channels (37 ha), overland flow generated a sediment load of $249 \mathrm{Mg}$ in 2010 and $278 \mathrm{Mg}$ in 2011. Of this total amount, $193 \mathrm{Mg}$ of overland flow sediments actually entered the paddy fields in 2010 and $219 \mathrm{Mg}$ in 2011 . The remainder of the sediments was exported from the watershed through the irrigation channel (Table 3). Again assuming average texture values, the input of overland flow to the paddy fields in 2011 hence consisted of $109 \mathrm{Mg}$ of sand, $66 \mathrm{Mg}$ of silt and $44 \mathrm{Mg}$ of clay (Table 4). Thus the combined addition to the paddy fields from reservoir outflow and overland runoff amounted to $318 \mathrm{Mg}$ of sand, $274 \mathrm{Mg}$ of silt and $240 \mathrm{Mg}$ of clay (Table 4).

The sediment load exported from the paddy fields on both banks of the river, calculated as the difference between Location A and Location B, was $469 \mathrm{Mg}$ in 2011 (Table 3), of which $60 \%$ was exported during the spring cropping season, and $40 \%$ during the summer crop. As the monitoring station in Location B was only installed in 2011, data for 2010 are not available. Combining all of these loads, the difference between inputs and export from the paddy resulted in a sedi- ment yield of $363 \mathrm{Mg}$ in total, or $28 \mathrm{Mg} \mathrm{ha}^{-1}$ that remained in the paddy fields in 2011. Since the load exported and the net paddy load are differences between positive numbers (loads measured at Location A minus B for the export, and inputs minus export for the net load), the lower limit of the confidence interval for these two estimates can become negative (Table 3). Negative load estimates can be interpreted as net sediment trapping of the paddy area. Looking at the texturespecific loads (Table 4), the sediments exported from the paddies consisted mostly of finer material. Thus, in 2011 approximately $326 \mathrm{Mg}$ of silt and $141 \mathrm{Mg}$ of clay were exported from the rice fields. Combining inputs and losses, $315 \mathrm{Mg}$ of sand and $99 \mathrm{Mg}$ of clay remained behind in the paddy fields over the whole year, while a net amount of $52 \mathrm{Mg}$ of silt was lost from the 13 ha paddy area (Table 4 ).

\subsection{Watershed sediment yield}

The total sediment yield of the subwatershed, ending at Location B, was $2234 \mathrm{Mg}$ in 2011. This amount was exported via two pathways. First, the irrigation canal distributed $150 \mathrm{Mg}$ from the reservoir and $59 \mathrm{Mg}$ from the upland area through overland flow into the neighboring catchment (Table 3, Fig. 6). Second, the river exported $2026 \mathrm{Mg}$ from the subwatershed at Location B. Of these $2026 \mathrm{Mg}$, a total of $469 \mathrm{Mg}$ consisted of runoff from the paddy fields. The remaining $1556 \mathrm{Mg}$ that was lost through the river, originated from the surface reservoir: the reservoirs' spillover allows excess water to flow into the river whenever the reser- 


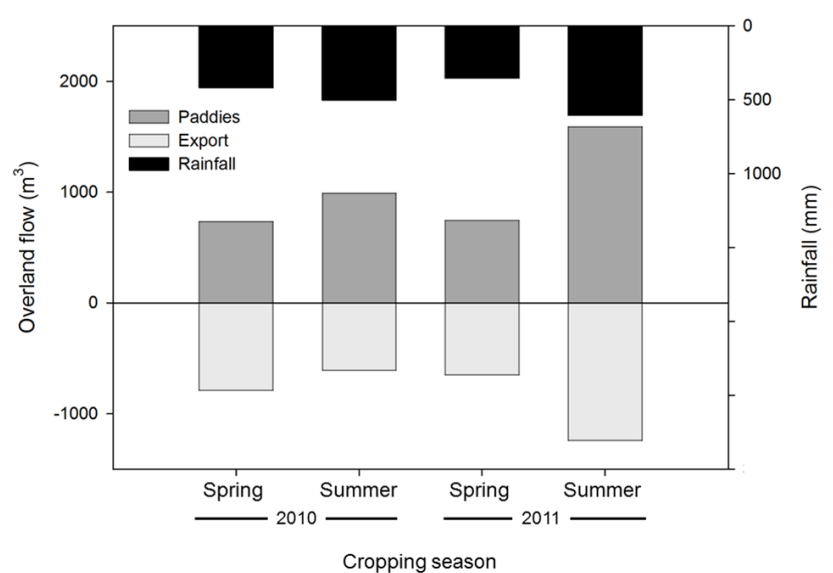

Figure 5. Total amount of water from overland flow during rainfall events, irrigated to the paddy fields and exported (negative on the $y$ axis) out of the subwatershed via the irrigation channel per rice crop per year, and amount of rainfall per rice crop (note the different units on the $y$ axis compared to Fig. 2).

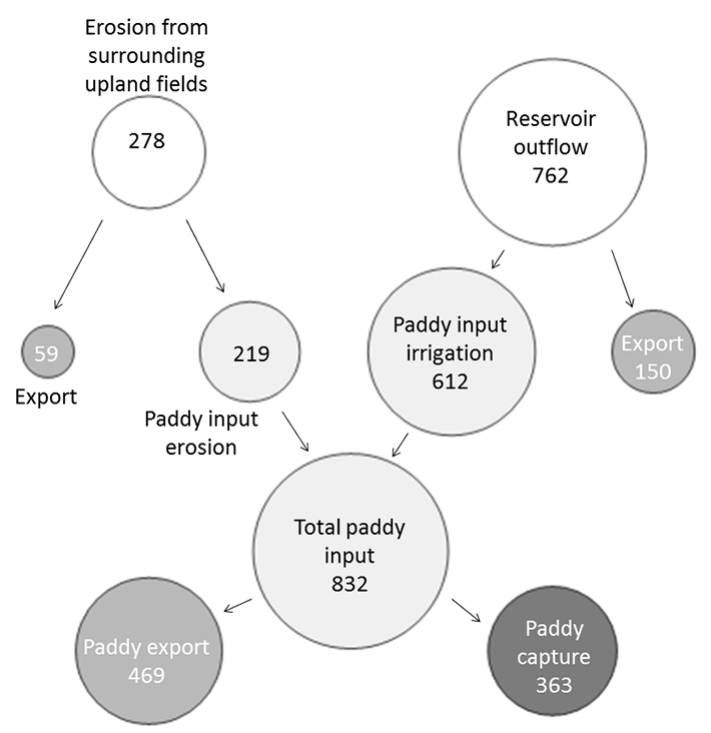

Figure 6. Sediment flow chart for 2011. Bubble size corresponds to size of the sediment load (in $\mathrm{Mg} \mathrm{a}^{-1}$ ).

voirs' maximum capacity is reached. For the larger watershed of 200 ha, which contains the aforementioned subcatchment, the annual sediment yield was $6262 \mathrm{Mg}$ in 2010 and $5543 \mathrm{Mg}$ in 2011.

\section{Discussion}

\subsection{Upland sediment contribution to the irrigation system}

The largest peak of suspended sediment concentration found in this study was 2-5 times higher compared with the high- est values found in other southeast Asian studies (Ziegler et al., 2014; Valentin et al., 2008) and the corresponding event contributed $23 \%$ of the total annual sediment load transported by overland flow to the irrigation channel in 2011 . The difference in sediment concentration with other studies is most likely due to the more gentle slopes $(8-15 \%)$ present in the watershed study of Valentin et al. (2008), whereas steep slopes up to $65 \%$ are found in our watershed. Both other studies, however, which contain the highest values found for southeast Asia in literature, also used a stormbased sampling strategy, underscoring the importance of capturing the highest events in order to reliably assess the erosivity of mountainous catchments. Horowitz et al. (2014) reported that calendar-based sampling typically underestimates constituent transport, while event-based sampling does not. Capturing the highest peaks is crucial, as the importance of single, high-intensity storms for sediment yield in tropical areas is increasing due to climate change. In the monsoon climates of southeast Asia, a rise in extreme, high-intensity rainfall events is expected (IPCC, 2013) and as single large storms already have such a substantial effect on the annual sediment load; in the future they can be expected to dominate annual sediment loads.

Our estimated upland sediment load of $278 \mathrm{Mg} \mathrm{a}^{-1}$ in 2011 translates into an annual soil loss of $7.5 \mathrm{Mg} \mathrm{ha}^{-1}$. This result should be interpreted as an average yield at the watershed level, not as a representative erosion rate at the plot level. This estimate is well within the order of magnitude reported by watershed-scale measurements. For instance, Valentin et al. (2008) monitored sediment yield from 27 catchments in mountainous southeast Asia and found an average total annual sediment yield of $3.4 \mathrm{Mg} \mathrm{ha}^{-1}$. Plot-scale studies, however, frequently report larger erosion rates than the $7.5 \mathrm{Mg} \mathrm{ha}^{-1}$ found in our study. Also in the Chieng Khoi commune, Tuan et al. (2014) recorded an erosion rate averaging $44 \mathrm{Mg} \mathrm{ha}^{-1} \mathrm{a}^{-1}$ for sediment fences in unbounded plots for maize-cassava intercropping systems. This discrepancy is typical when upscaling erosion rates (de Vente and Poesen, 2005), as processes are not linear. Erosion can be concentrated at certain hotspots, and rill erosion, internal deposition and filtering processes (e.g., hedges) leave part of the eroded sediments behind within the watershed (Verstraeten and Poesen, 2001). Indeed, in our watershed, the mix of homesteads, maize and maize-cassava cropping and trees on the hills affect both sediment delivery pathways and redeposition opportunities. The plot-level soil loss on upland fields can thus be expected to exceed the value of $7.5 \mathrm{Mg} \mathrm{ha}^{-1}$ that enters the irrigation channel, as a proportion of eroded sediments will be deposited before ever reaching the channel. Nevertheless, even using the conservative estimate of $7.5 \mathrm{Mg}$ and assuming a bulk density of around $1.2 \mathrm{~g} \mathrm{~cm}^{-3}$, this result entails a loss of around $0.6 \mathrm{~mm}$ of soil per year, a value that is well above the soil loss of $2.5 \mathrm{Mg} \mathrm{ha}^{-1} \mathrm{a}^{-1}$ that is generally considered tolerable (Schertz, 1983). 


\subsection{Sediment trap efficiency of paddy fields}

Surface reservoir water was the largest contributing source to suspended sediment inputs for the paddy fields, with only one quarter of sediment inputs to the paddy fields coming from overland flow in both years. When looking at the sediment quality rather than sediment loads, however, the importance of overland flow increased for sand, with $34 \%$ of the total paddy inputs originating from erosion in 2011. Therefore, while irrigation was the main driver behind water and sediment fluxes in this irrigated catchment, overland flow plays an important role in transfers that could affect plant production and long-term soil fertility.

Paddy runoff amounted to a total of $469 \mathrm{Mg}$ for the $13 \mathrm{ha}$ area in 2011 , or $36 \mathrm{Mg} \mathrm{ha}^{-1} \mathrm{a}^{-1}$ of sediments leaving the rice fields. The majority of paddy sediment export $(60 \%)$ took place during the spring season, and can thus be related to overland runoff flowing through the paddies early in the year, when upland fields were bare as the maize crop was not yet established. Hence, intensive land preparation for maize planting and lack of soil cover in spring resulted in a large supply of readily erodible material on the hills. Short-duration, high-intensity spring storms combined with this sediment supply, led to rapid and large inputs of sediment which passed through the paddies. As a result, sediments had little time to settle, thus reducing filter effectiveness of the rice fields and culminating in less trapping and more sediment export from the paddies during the first crop.

Comparing inputs to paddy field exports suggests that the rice area trapped $44 \%$ of the combined reallocated sediments from reservoir irrigation water and direct runoff from the upland areas. Similarly, Mingzhou et al. (2007) found that the sediment load in the irrigation water resulted in a net deposition, rather than erosion from paddy fields, which led to an additional $4 \mathrm{~cm}$ of top soil through irrigation deposits after 50 years of irrigation. While the paddies in our study were a net overall sediment sink, results also showed that the sand fraction was preferentially deposited and was in fact almost entirely captured in the paddies, forming a net deposition of $23 \mathrm{Mg} \mathrm{ha}^{-1} \mathrm{a}^{-1}$. About half of the imported clay remained behind in the fields, or a total of $8 \mathrm{Mg} \mathrm{ha}^{-1} \mathrm{a}^{-1}$. For silt, the overall balance was negative, with $5 \mathrm{Mg} \mathrm{ha}^{-1}$ of silt exported on an annual basis. This preferential deposition is likely to have consequences, as long-term fertility of paddy fields is contingent upon the particle size distribution of the soils for physical soil properties, e.g., clay content exceeding $20 \%$ is favorable for puddling (De Datta, 1981). In our study area, top soil in the paddy fields is predominantly silty, with an average of $19 \%$ sand, $68 \%$ silt and $13 \%$ clay (Schmitter et al., 2010). With an estimated deposition of $23 \mathrm{Mg} \mathrm{ha}^{-1} \mathrm{a}^{-1}$ of sand and $8 \mathrm{Mg} \mathrm{ha}^{-1} \mathrm{a}^{-1}$ of clay in the paddies, and a removal of $4 \mathrm{Mg} \mathrm{ha}^{-1} \mathrm{a}^{-1}$ of silt, textural changes can be expected to take place over time. While the clay fraction is expected to add sediment-associated nutrients to the paddies, and thus increase the indigenous nutrient supply for rice, the sand deposits are much larger (76\% of all inputs) and will thus drive the long-term fertility changes in paddy topsoil. Assuming a puddling depth of roughly $25 \mathrm{~cm}$ and a bulk density of $1.2 \mathrm{~g} \mathrm{~cm}^{-3}$, the sand fraction would dominate after approximately 50 years of these continued inputs. But not all fields would have the same longevity, as sediment inputs do not affect the fields equally. Previous research has shown that sedimentation in rice cascades shows spatial variability, and that fields closest to the water source receive most of the coarse material, the yield declining with decreasing distance to the water source (Schmitter et al., 2010). Thus for certain fields closer to the water source, sand content would increase more rapidly, which is indeed already visible in the study area: paddies higher up on the cascades were often seen to display poor water holding capacity.

Similar composite agricultural systems with permanent upland cultivation on the hills and irrigated rice in the valleys contain $60 \%$ of the total paddy area in northern Vietnam (Rutten et al., 2014). Consequently, a large agricultural area is potentially affected by such upland-lowland linkages. Eliminating the direct entry of Hortonian overland flow into the irrigation channel, for example by runoff ditches, is one way to prevent up to one-third of the total sand inputs from entering the rice fields and thus to protect the food security of the people in the mountainous areas of northern Vietnam, who depend on rice as their staple food. This solution is not sustainable in the long run from a systems-approach perspective, as the fertility loss of the uplands would affect income when the cash crop income is declining. But with the current high maize prices, it is challenging to identify sustainable hillside land uses that are attractive to local stakeholders (Keil et al., 2008), and deviating direct runoff from entering the paddies would at least be an interim solution. It would, however, also lead to substantial losses of nutrients (Dung et al., 2008) which could not be recycled.

\subsection{Buffer capacity of the reservoir}

For the sediment yield measured at Location B, the outlet of the subwatershed, the vast majority of sediments (1557 out of $2064 \mathrm{Mg}$ ) stem from the reservoir which spills over into the river when it reaches maximum capacity. In that sense, the bulk of sediments are merely passing through the subwatershed, having been captured in the reservoir after runoff from the surrounding 490 ha of upland fields. Reservoir outflow is thus not only the largest contributor to sediment transport in our paddy area within the watershed but also has a propagating effect beyond the watershed scale: the river water leaving the watershed is either reused for irrigating paddies in downstream catchments, or will finally end up in the Da river. In either case, the surface reservoir buffers direct sediment inputs that could negatively affect paddy production and river water quality, as average sediment concentrations released from the reservoir were much lower than those measured during rainfall events in the channel $\left(240 \mathrm{mg} \mathrm{L}^{-1}\right.$ vs. $\left.1200 \mathrm{mg} \mathrm{L}^{-1}\right)$. 
The water in the reservoir also had a lower sand and higher silt and clay content, and sediment profiles in the lake indeed confirmed this preferential settling of coarse material. Weiss (2008) showed that soil profiles taken at the lake bottom had a sediment texture of $40-75 \%$ sand, $20-50 \%$ silt and 5-14\% clay. The reservoirs' filtering effect can be expected to be stronger beyond the watershed, as coarser particles will be trapped preferentially in closer vicinity to the source. While large enough to substantially affect rice production, the amount of sediments trapped by the paddy fields is moderate $(12 \%)$ compared to the total amount exported from the watershed by reservoir spillover export. In light of these proportions, effects of climate change and declining soil fertility in upland areas will not remain on-site but can be expected to propagate beyond the watershed, and also affect areas further downstream.

\section{Conclusions}

The sediment budget for a 13 ha paddy area in a composite agricultural system with permanent maize cultivation on the uplands showed that rice fields at the watershed level are a net sink for sediments, i.e., trapping $46 \%$ of the total sediment inputs. Irrigation water, providing $74 \%$ of the total inputs of $832 \mathrm{Mg}$, was a larger sediment contributor than direct overland flow from the surrounding upland fields. The irrigation water, however, provided predominantly silty material, while direct runoff sediments had a sandy texture. In the past, extensive swiddening systems with their diverse landscape patterns would have delivered little and mostly fine, fertile sediments to paddy fields via direct overland flow. Recent intensification of upland cropping has transformed these previously beneficial inputs into an increased risk for the long-term sustainability of rice production, threatening productivity of upland cropping and paddy yields. The reservoir, however, acts as a buffer by protecting both the rice fields within the watershed, and paddies and water quality further downstream, from unfertile sediment inputs - thus expanding the lifetime of the paddies.
Our results show the importance of quantifying uplandlowland linkages within and between watersheds, and can be used by scientists, policy makers and extension services to give suitable recommendations to the large group of people in mountainous southeast Asia who, under influence of population pressure, have gone from practicing composite swidden agriculture to an intensified cropping system with permanent maize cultivation on the hills. Preventing overland flow from reaching the paddy fields, for example, could prevent up to $8 \mathrm{Mgha}^{-1} \mathrm{a}^{-1}$ of sand per year, or one-third of the total sand deposits, from entering the rice fields. More diversified, sustainable and acceptable approaches, however, benefitting both upland fields as well as downstream paddies, need to be developed at the same time.

\section{Data availability}

The source code for the bootstrap analysis with the SAS software that was used for the load estimates and corresponding confidence intervals is freely available at https: //www.uni-hohenheim.de/bioinformatik/beratung/index.htm together with necessary input files for testing. The full data set is available from the authors upon request (hanna.slaets@gmail.com). 


\section{Appendix A:}

Calculating a measure of uncertainty on a sediment load is not trivial. The final value is a sum of instantaneous loads, and those loads are the product of two predicted values, concentration and discharge, which are not independent of each other, as discharge is a predictor variable for concentration. Additionally, the predicted values are on the transformed scale, and there is serial correlation in the sediment concentration data, as samples are taken closely together in time.

In order to calculate $95 \%$ confidence intervals on the sediment loads, a bootstrap method was developed that addresses all of these issues (Slaets et al., 2016). The bootstrap is a Monte-Carlo-type method that generates the sampling distribution of a statistic by resampling a large number of times, either from the original observations or from a parametric distribution, to obtain new bootstrap data sets, on each of which the sediment load is calculated. This large number of bootstrap sediment loads provides an empirical distribution, which can be used to estimate the 2.5 th and 97.5 th percentiles. These percentiles are the limits of the $95 \%$ confidence interval (Efron and Tibshiriani, 1993). In our data set, 2000 bootstrap replicates resulted in smooth histograms and reproducible percentiles. The developed method thus accounts for uncertainty in the parameter estimates of both the discharge and sediment rating curves, and uncertainty due to residual scatter in the sediment concentrations. In this approach, the final bootstrap process consists of three steps:

- non-parametric bootstrapping of the (stage, discharge) pairs in order to obtain 2000 bootstrap stage-discharge equations, and thus 2000 time series predictions for bootstrapped discharge;

- non-parametric bootstrapping of the sediment concentration data set, by drawing whole events (to keep the serial correlation intact) and individual base-flow samples, resulting in 2000 bootstrap sediment rating curves, and thus 2000 time series predictions of continuous suspended sediment concentration;

- adding a simulated error term to the concentration predictions to account for inherent residual scatter in the data and to facilitate the back transformation from the log scale. 


\section{The Supplement related to this article is available online at doi:10.5194/bg-13-3267-2016-supplement.}

Acknowledgements. The authors gratefully acknowledge the German Research Foundation (DFG) who funded the Uplands Program (SFB 564), the project in which this study took place, in collaboration with the Center for Agricultural Research and Ecological Studies (CARES); the EnBW Rainforest Foundation which provided additional funding; field technicians Do Thi Hoan and Nguyen Duy Nhiem for their hard work collecting the data; lake manager Nguyen Xuan Truong who provided the reservoirs' water level data; Nguyen Huu Thanh, lab technicians Dang Thi Thanh Hue and Phan Linh at the Central Water \& Soil Lab at Hanoi University of Agriculture where the water samples were analyzed; and Hans-Peter Piepho for his valued input to the manuscript.

Edited by: M. Sarin

\section{References}

ASTM: Standard D3977-97, Standard Test Methods for Determining Sediment Concentration in Water Samples, ASTM International, West Conshohocken, PA, 2013.

Bray, F.: The rice economies: technology and development in Asian societies, Blackwell, London, 1986.

Cao, Z. H., Ding, J. L., Hu, Z. Y., Knicker, H., Kögel-Knabner, I., Yang, L. Z., Yin, R., Lin, X. G., Dong, Y. H., Cao, Z. H., Hu, Z. Y., Yang, L. Z., Yin, R., Lin, X. G., and Dong, Y. H.: Ancient paddy soils from the Neolithic age in China's Yangtze River Delta, Naturwissenschaften, 93, 232-236, doi:10.1007/s00114006-0083-4, 2006.

Chaplot, V. and Poesen, J.: Sediment, soil organic carbon and runoff delivery at various spatial scales, Catena, 88, 46-56, 2012.

Chaplot, V., Khampaseuth, X., Valentin, C., and Le Bissonnais, Y.: Interrill erosion in the sloping lands of northern Laos subjected to shifting cultivation, Earth Surf. Proc. Land., 32, 415428, doi:10.1002/esp.1411, 2007.

Clemens, G., Fiedler, S., Cong, N. D., Van Dung, N., Schuler, U., and Stahr, K.: Soil fertility affected by land use history, relief position, and parent material under a tropical climate in NWVietnam, Catena, 81, 87-96, doi:10.1016/j.catena.2010.01.006, 2010.

De Datta, S. K.: Principles and Practices of Rice Production, John Wiley \& Sons, Inc., New York, 1981.

de Vente, J. and Poesen, J.: Predicting soil erosion and sediment yield at the basin scale: Scale issues and semi-quantitative models, Earth-Sci. Rev., 71, 95-125, doi:10.1016/j.earscirev.2005.02.002, 2005.

Dobermann, A., Cassman, K., Mamaril, C., and Sheehy, J.: Management of phosphorus, potassium, and sulfur in intensive, irrigated lowland rice, Field Crop. Res., 56, 113-138, 1998.

Dung, N., Vien, T., Cadisch, G., Lam, N., Patanothai, A., Rambo, T., and Truong, T.: A nutrient balance analysis of the composite swiddening agroecosystem, in: Farming with Fire and Water the Human Ecology of a Composite Swiddening Community in
Vietnam's Northern Mountains, edited by: Vien, T. D., Rambo, T. A., and Lam, N. T., Kyoto University Press and Trans Pacific Press, Melbourne, 456 pp., 2009.

Dung, N. V., Vien, T. D., Lam, N. T., Tuong, T. M., and Cadisch, G.: Analysis of the sustainability within the composite swidden agroecosystem in northern Vietnam, 1. Partial nutrient balances and recovery times of upland fields, Agr. Ecosyst. Environ., 128, 37-51, 2008.

Efron, B. and Tibshirani, R. J.: An Introduction to the Bootstrap, Chapman \& Hall/CRC Monographs on Statistics \& Applied Probability, Boca Raton, 1993.

FAO: AQUASTAT website, Food and Agriculture Organization of the United Nations, available at: http://www.fao.org/nr/water/ aquastat/countries_regions/VNM/index.stm, last access: $20 \mathrm{Au}-$ gust 2015.

Ferguson, R. I.: River loads underestimated by rating curves, Water Resour. Res., 22, 74-76, doi:10.1029/WR022i001p00074, 1986.

Gafur, A., Jensen, J. R., Borggaard, O. K., and Petersen, L.: Runoff and losses of soil and nutrients from small watersheds under shifting cultivation (Jhum) in the Chittagong Hill Tracts of Bangladesh, J. Hydrol., 274, 30-46, doi:10.1016/S00221694(02)00351-7, 2003.

Gong, Z. T., Zhang, G. L., and Chen, Z. C.: Pedogenesis and Soil Taxonomy, Science Press, Bejing, 2007.

Häring, V., Fischer, H., and Stahr, K.: Erosion of bulk soil and soil organic carbon after land use change in northwest Vietnam, Catena, 122, 111-119, doi:10.1016/j.catena.2014.06.015, 2014.

Herschy, R. W.: Streamflow measurement, CRC Press, Boca Raton, 1995.

Horowitz, A. J., Clarke, R. T., and Merten, G. H.: The effects of sample scheduling and sample numbers on estimates of the annual fluxes of suspended sediment in fluvial systems, Hydrol. Process., 29, 531-543, doi:10.1002/hyp.10172, 2014.

Huang, L. M., Thompson, A., Zhang, G. L., Chen, L. M., Han, G. Z., and Gong, Z. T.: The use of chronosequences in studies of paddy soil evolution: A review, Geoderma, 237, 199-210, doi:10.1016/j.geoderma.2014.09.007, 2015.

IPCC: Climate change 2013: The physical science basis. Contribution of working group I to the fifth assessment report of the intergovernmental panel on climate change, Cambridge, United Kingdom and New York, NY, USA, 1535 pp., 2013.

Keil, A., Saint-Macary, C., and Zeller, M.: Maize boom in the uplands of Northern Vietnam: economic importance and environmental implications, Discussion Paper no. 4/2008, University of Hohenheim, Department of Agricultural Economics and Social Sciences in the Tropics and Subtropics, 2008.

Kundarto, M., Agus, F., Maas, A., and Sunarminto, B. H.: Water balance, soil erosion and lateral transport of NPK in rice-field systems of sub watershed Kalibabon Semarang, Multifunctionality of Paddy Fields, Bogor, Indonesia, 2 October 2002 (in Indonesian).

Lacombe, G., Ribolzi, O., de Rouw, A., Pierret, A., Latsachak, K., Silvera, N., Pham Dinh, R., Orange, D., Janeau, J.-L., Soulileuth, B., Robain, H., Taccoen, A., Sengphaathith, P., Mouche, E., Sengtaheuanghoung, O., Tran Duc, T., and Valentin, C.: Afforestation by natural regeneration or by tree planting: examples of opposite hydrological impacts evidenced by long-term field monitoring in the humid tropics, Hydrol. Earth Syst. Sci. Discuss., 12, 12615-12648, doi:10.5194/hessd-12-12615-2015, 2015. 
López-Tarazón, J., Batalla, R., Vericat, D., and Balasch, J.: Rainfall, runoff and sediment transport relations in a mesoscale mountainous catchment: the River Isábena (Ebro basin), Catena, 82, 2334, 2010.

Maglinao, A. R., Valentin, C., and Penning de Vries, F.: From soil research to land and water management: harmonizing people and nature, In: Proceedings of the IWMI-ADB Project Annual Meeting and 7th MSEC Assembly, Vientiane, Laos, 2-7 December 2002, IWMI, 2003.

Mai, V. T., van Keulen, H., Hessel, R., Ritsema, C., Roetter, R., and Phien, T.: Influence of paddy rice terraces on soil erosion of a small watershed in a hilly area of Northern Vietnam, Paddy and Water Environment, 11, 285-298, doi:10.1007/s10333-0120318-2, 2013.

Mingzhou, Q., Jackson, R. H., Zhongjin, Y., Jackson, M. W., and Bo, S.: The effects of sediment-laden waters on irrigated lands along the lower Yellow River in China, J. Environ. Manage., 85, 858-865, doi:10.1016/j.jenvman.2006.10.015, 2007.

Rüth, B. and Lennartz, B.: Spatial variability of soil properties and rice yield along two catenas in southeast China, Pedosphere, 18, 409-420, doi:10.1016/S1002-0160(08)60032-6, 2008.

Rutten, M., Van Dijk, M., Van Rooij, W., and Hilderink, H.: Land use dynamics, climate change, and food security in Vietnam: A global-to-local modeling approach, World Development, 59, 2946, doi:10.1016/j.worlddev.2014.01.020, 2014.

Schertz, D. L.: The basis for soil loss tolerances, J. Soil Water Conserv., 38, 10-14, 1983.

Schmitter, P., Dercon, G., Hilger, T., Thi Le Ha, T., Huu Thanh, N., Lam, N., Duc Vien, T., and Cadisch, G.: Sediment induced soil spatial variation in paddy fields of Northwest Vietnam, Geoderma, 155, 298-307, doi:10.1016/j.geoderma.2009.12.014, 2010.

Schmitter, P., Dercon, G., Hilger, T., Hertel, M., Treffner, J., Lam, N., Duc Vien, T., and Cadisch, G.: Linking spatiotemporal variation of crop response with sediment deposition along paddy rice terraces, Agr. Ecosyst. Environ., 140, 34-45, 10.1016/j.agee.2010.11.009, 2011.

Schmitter, P., Fröhlich, H., Dercon, G., Hilger, T., Thanh, N. H., Lam, N., Vien, T., and Cadisch, G.: Redistribution of carbon and nitrogen through irrigation in intensively cultivated tropical mountainous watersheds, Biogeochemistry, 109, 133-150, doi:10.1007/s10533-011-9615-x, 2012.

Slaets, J. I. F., Schmitter, P., Hilger, T., Lamers, M., Piepho, H. P., Vien, T. D., and Cadisch, G.: A turbidity-based method to continuously monitor sediment, carbon and nitrogen flows in mountainous watersheds, J. Hydrol., 513, 45-57, doi:10.1016/j.jhydrol.2014.03.034, 2014.
Slaets, J. I. F., Piepho, H.-P., Schmitter, P., Hilger, H. P., and Cadisch, G.: Quantifying uncertainty on sediment loads using bootstrap confidence intervals, available at: https://www. uni-hohenheim.de/bioinformatik/beratung/index.htm, 2016.

Tuan, V. D., Hilger, T., MacDonald, L., Clemens, G., Shiraishi, E., Vien, T. D., Stahr, K., and Cadisch, G.: Mitigation potential of soil conservation in maize cropping on steep slopes, Field Crop. Res., 156, 91-102, doi:10.1016/j.fcr.2013.11.002, 2014.

Valentin, C., Agus, F., Alamban, R., Boosaner, A., Bricquet, J. P., Chaplot, V., de Guzman, T., de Rouw, A., Janeau, J. L., Orange, D., Phachomphonh, K., Do Duy, P., Podwojewski, P., Ribolzi, O., Silvera, N., Subagyono, K., Thiébaux, J. P., Tran Duc, T., and Vadari, T.: Runoff and sediment losses from 27 upland catchments in Southeast Asia: Impact of rapid land use changes and conservation practices, Agr. Ecosyst. Environ., 128, 225-238, doi:10.1016/j.agee.2008.06.004, 2008.

Verstraeten, G. and Poesen, J.: Factors controlling sediment yield from small intensively cultivated catchments in a temperate humid climate, Geomorphology, 40, 123-144, doi:10.1016/S0169555X(01)00040-X, 2001.

von Uexkuell, H. and Beaton, J.: A review of fertility management of rice soils, in: Proceedings of the 8th International Soil Correlation Meeting (VIII, ISCOM), Soil Conservation Service, edited by: Kimble, J., United States Department of Agriculture, Lincoln, Nebraska, 288-300, 1992.

Weiss, A. M.: Charcoal in sediment layers: A way to estimate land use intensification on reservoir siltation?, MS thesis, Institute of Plant Production in the Tropics and Subtropics, University of Hohenheim, Stuttgart, Germany, 2008.

Wold, H.: Estimation of principal components and related models by iterative least squares, Multivariate Analysis, 1, 391-420, 1966.

Ziegler, A. D., Giambelluca, T. W., Tran, L. T., Vana, T. T., Nullet, M. A., Fox, J., Vien, T. D., Pinthong, J., Maxwell, J. F., and Evett, S.: Hydrological consequences of landscape fragmentation in mountainous northern Vietnam: evidence of accelerated overland flow generation, J. Hydrol., 287, 124-146, doi:10.1016/j.jhydrol.2003.09.027, 2004.

Ziegler, A. D., Bruun, T. B., Guardiola-Claramonte, M., Giambelluca, T. W., Lawrence, D., and Thanh Lam, N.: Environmental consequences of the demise in swidden cultivation in montane mainland Southeast Asia: Hydrology and geomorphology, Hum. Ecol., 37, 361-373, doi:10.1007/s10745-009-9258-x, 2009.

Ziegler, A. D., Sidle, R. C., Phang, V. X. H., Wood, S. H., and Tantasirin, C.: Bedload transport in SE Asian streams - Uncertainties and implications for reservoir management, Geomorphology, 227, 31-48, doi:10.1016/j.geomorph.2014.01.015, 2014. 